\title{
The Role of Cloud Computing for the Enhancement of Teaching and Learning in Saudi Arabian Universities in Accordance with the Social Constructivism Theory: A Specialist's Point of View
}

\author{
https://doi.org/10.3991/ijet.v14i13.9557 \\ Farhan Yetaim Alenezi \\ Northern Border University (NBU), Arar, Kingdom of Saudi Arabia \\ drfarhan425@gmail.com
}

\begin{abstract}
This study aims to evaluate the role of Cloud Computing in enhancing teaching and learning in the Saudi Arabian government universities in the backdrop of the four principles of Social Constructivism Theory - Social Interaction, Previous Experience, Activity of a Learner, and the Development of Mental Skills. All of them have to be examined form the specialist's point of view as he/she will be responsible for integrating technology into the processes to support the whole ecosystem.

The study was conducted at 29 Saudi Arabian government universities, using a Quantitative Approach based on a Questionnaire. The study sample consisted of 84 Deans and Vice Deans of E-learning across all Saudi Arabian government universities, in the Academic Year 2016/2017. The results revealed a significant role for Cloud Computing for teaching and learning enhancement in the Saudi Arabian universities in accordance with the construct outlined above.
\end{abstract}

Keywords - Cloud Computing, Social Constructivism, E-learning, Higher Education, Saudi Arabia

\section{$1 \quad$ Introduction}

There is no doubt in it that universities have been consistently playing leading role through scientific and technical advancements, especially with respect to the cognitive and intellectual development of their communities. According to Buckner (2017), who investigated the impact of the role of both Private and Public Sector higher educational institutions for over five decades on the demographic and economic factors, has found an impressive improvement in higher education worldwide. This progress coincided with the rapid development of information and communication technology, making it imperative for the universities to leverage the modern tools and applications through integrating them in the teaching and learning environments.

Cloud Computing is currently regarded as a powerful information and communication technology application on account of its multiple advantages. It has a shareable advanced computing infrastructure which can be shared among them. It uses 
a network of the remote Computing devices (servers) hosted on the Internet to manage, process and store data, without the need for any prior knowledge or experience, or even infrastructure control. Cloud Computing applications are regarded as one of the fastest growing tools in the Kingdom of Saudi Arabia (Business, 2015), with the Saudi Arabian government investing heavily in the e-Services in its quest for e-Governance for the purpose of improving the Public Sector services, including education. One of the initiatives of the second national e-Government is to build a Cloud Computing delivery model for the government agencies (Alghamdi \& Beloof, 2014).

Cloud Computing is defined by the National Institute of Standards and Technology (NIST) as 'a model for enabling ubiquitous, convenient, on-demand network access to a shared pool of configurable computing resources (for example, networks, servers, storage, applications, and services) that can be rapidly provisioned and released with minimal management efforts or for the service provider interaction' (Mell \& Grance, 2011). While Cloud Computing offers much useful support in education, its other important uses are software applications, infrastructure, platform system, communications and data storage (Cisco, 2016; Zafar et al., 2017).

Cloud Computing has many new functions such as teaching and learning designs, teaching and learning experiences, interaction and adapting Cloud environments to the user needs, opening up to the potential to deliver a common experience which will stimulate new types of requirements, needs, and user activities (Sun \& Shu, 2016). Further, the adoption of Cloud Computing in education has the potential to enhance knowledge management (Arpaci, 2017). In addition, implementation of Cloud Computing services helps to improve student experiences and learning (Naidu et al., 2019).

As Li (2018) and Jalgaonkar \& Kanojia (2013) summarized, the major benefits of using Cloud Computing in higher education is to reduce costs, effectively achieve the sharing of educational resources and enhance the level of educational modernization, direct access to applications services and resources of academic research from anywhere and at any time, in order to support teaching and learning, account management, providing software, constant openness of students and faculty members in an advanced business and research environment to increase the functional capacity of faculty members, and provide synchronous and asynchronous communication.

It has been found that Cloud Computing also helps in providing intelligent teaching and learning in the synchronous and social environments, as well as through an integrated yet flexible teaching system. Other benefits include, training facilities for scientific innovation, ease of access to educational contents and research, websites for collaboration and knowledge building, and also support to students, faculty members, and researchers with an easy facilitation and exchange of knowledge (Huang, 2017). Similarly, McDougall (2015) argues that this type of teaching and learning is more meaningful and incisive, thus produces high levels of engagement and positive teaching and learning outcomes as compared with the traditional forms of content-based teaching.

The use of Cloud Computing in higher education provides many benefits, such as simplifying IT complexities, improving the quality of Information Technology (IT), and allowing the IT managers to focus on their vision and the key objectives in higher 
education institutions. Moreover, Cloud Computing is flexible, scalable and costefficient thus significantly reduce the costs related to Information \& Communication Technology services. It can thus help the institutions to focus on the quality of their outputs, and their full-time research and teaching (Changchit, 2014).

Cloud Computing provides the students abundant scope to share teaching and learning materials, references, research papers and scientific articles, to name but a few, through the files stored on Cloud storage services, such as Dropbox or Google Docs (Al-Samarraie \& Saeed, 2018). Cloud Computing provides a synchronization feature, which enables the students, who have access to the Cloud to work together effectively, without the need for an external storage or emails, or any secondary storage for the exchange of information (Murah, 2012).

The sharing of videos, programs, photos, information, blogging and collaborative software etc., that had been formerly unavailable or expensive, is fast becoming available free nowadays. Anyone can now access to such sources through their own web browsers. And, therefore it is not surprising to find the students using such resources. They make it imperative for the educational institutions to take advantage of such services effectively (Vance, Merati, Yang \& Yuan, 2016).

Hussona's (2016) study at Al-Aqsa University confirmed the effectiveness of Cloud Computing in teaching and learning or training, and for strengthening the ecosystem to use Cloud Computing and scale it. Training was conducted via a blog based on the Cloud Computing capabilities. A study conducted by $\mathrm{Li}$ (2016) designed a multimedia teaching system based on Cloud Computing and introduced its design idea, system structure, and applications. The teaching experiment has shown that this system has a better teaching application effect and results in the better academic performance of students in comparison to the traditional teaching methods. It has also been found to improve students' comprehension and has both operability and feasibility.

Denton (2012) has reported that there are many advantages of Cloud Computing in the field of education, such as through the use of Google Docs and Microsoft Office Live, which have potentiality to promote and support teaching methods based on the constructive and collaborative teaching and learning steps through the use of social constructivism theory. For example, using Cloud Computing applications and services, sharing files, sharing materials, sharing documents, and e-publishing motivates the education departments across the countries to adopt such technologies as they support collaborative and interactive learning, which is consistent with the current norms that suggest three key tenets of social constructivist teaching and learning environment: Constructive activity; teacher-student interaction, and social activity (Alt, 2014).

A study conducted by Ismail (2016) emphasized the importance of advisers in the use of Cloud Computing in learning. Her findings suggest that there are statistically significant differences in the grades of students in the Instructor-led groups compared to those without an Instructor. Tashkandi \& Al-Jabri (2015) recommended integrating Cloud Computing into Saudi Arabian higher education offering a special model for the understanding of the induction process. In addition, Sabi et al., (2016) proposed a model to investigate and adopt Cloud Computing in education in the developing countries, which reinforces the importance of Cloud Computing in higher education. 
Likewise, Bhatiasevi \& Naglis (2016) study used the data that was collected from two leading universities in Thailand - Mahidol University International College and Thammasat University, concluding that university students believed that Cloud Computing was easy to use, and had innumerable benefits. The students had great confidence in its advantages and services. That study also found positive attitudes among the students, and an urgent desire to integrate Cloud Computing for usage in educational sector.

Similarly, Alfifi (2015) reported a number of advantages of Cloud Computing, which in turn motivated the stakeholders in the higher education institutions to integrate Cloud Computing into their operations. The sample study population consisted of 106 CIOs in higher education institutions in the United States of America (USA), who were responsible for making decisions for both technology and business policies within their organizations.

This study was conducted by using a distributed Questionnaire, and the results identified the seven key factors: moving stored data in the Cloud from one provider to another, service quality, flexibility of traditional systems, adequate safeguards to store data, portability, Cloud liability, and transparency of the service-level agreements. The results also showed a Cloud-computing adoption by CIOs in higher education of more than 93 per cent.

The theory of Social Constructivism came to offer a new concept of teaching and learning as a building process inside the learner through interaction with others (Freiberg \& Driscoll, 2000). This theory was pioneered by the Russian psychologist Lev Vygotsky, who perceived that mental development started from the outside leading into the interior, where the roots of internal processes in a person were created through interaction with others, and stressed that teaching and learning was a process through which learners might learn new knowledge and make sense of it on the basis of their prior knowledge and experience (Vygotsky, 1978).

The highlights of Wray and Lewis (1997) identifying the four important principles regarding the Social Constructivism Theory, which are as mentioned here, further describes:

- The importance of social interaction and discussion in order to build knowledge.

- The learner builds new knowledge based on the previous experiences, and needs help to link between the past and subsequent learning.

- The learner has to be active and effective in the teaching and learning process, and where the meaningful context is important to learning, we have to remember that what is relevant for a teacher is not necessarily equally relevant to the learner.

- Attention to the development of higher mental skills.

It is important in this area to look at the relationship between the Social Constructivist Theory and Cloud Computing. Many researchers assert that Social Constructivism Theory applies not only to education in general, but also to be applied further, in e-learning in particular, including Cloud Computing (Dahlberg, et al., 2017; Mitakos et al., 2014). 
The research by Huang \& Liu (2013) shed light on the role of Cloud Computing in the education sector that learner's personal environments leave positive impact through the construction strategy of the collaborative teaching and learning steps. By looking at the advantages of Cloud Computing services as well as looking at the principles of the Social Constructivism Theory, a clearly strong link appears between them. We find that Cloud Computing supports the foundations of the Social Constructivism Theory, which provides the learners with good opportunity to build their knowledge via interaction and discussions, and through the exchange of educational and research materials, sharing of information and educational programs among the students as well as faculty members, through the files stored on a storage service in Cloud Computing, like Dropbox.

It benefits their previous experiences and builds on their new experiences through such interactions. The nature of services, benefits, and use of Cloud Computing makes it imperative that learners play a more active role that a teacher who is just a facilitator. Many researchers also emphasize the role of Cloud Computing in the provision of training facilities for the development of scientific innovation skills, development of skills and mental capacity besides providing an integrated and flexible teaching system.

This correlation is best understood from a research by Denton (2012) that there is a causal relation among Constructivism, Cooperative Learning, and Cloud Computing to enhance the Instruction steps. It becomes possible through the multiplied tools. It supports, and is consistent with the social constructivism theory's principles in teaching and learning which focuses on the importance of social interaction in the construction of knowledge, based on the previous experiences of learners. It also supports the importance of education to prove meaningful, as well as the importance of learner to be active in their concentrated learning, paying attention to the development of mental skills.

\section{Statement of the Problem}

It has been brought into notice above that the importance of integration of technology in general, and Cloud Computing in particular in the universities, besides the benefits of services and advantages can't be ruled out. It fits well with various theories of learning, especially with the Social Constructivism Theory. The Powell \& Cody (2009) study reveals that efficient classrooms depend heavily on the constructivist strategies for cognitive learning.

Today, Cloud Computing services and the nature of their uses supports the foundations of the Social Constructivism Theory, where Cloud Computing introduces educational environments based on teaching and learning which has to take place in the framework of cooperation and social interaction in order to build knowledge and disseminate that to others. In turn, it helps to develop an individual's intellectual, social, and scientific skills.

Through the work of this researcher in the field of higher education in the Kingdom of Saudi Arabia, it is felt that there is a need to investigate the role of Cloud Computing for the enhancement of teaching and learning in the Saudi Arabian universities in 
accordance with the four principles of Social Constructivism Theory (Social Interaction, Previous Experiences, Activity of the Learner, Development of Mental Skills), from the point of view of specialists as well as those responsible for integrating technology to support teaching and learning at such universities.

Through answering the following questions, this study seeks to answer the main question of the study - what is the role of Cloud Computing in enhancing e-learning in Saudi Arabian universities based on the principle of Social Constructivism Theory from a specialists' point of view?

- What is the role of Cloud Computing in enhancing teaching and learning in the Saudi Arabian universities based on the principle of social interaction?

- What is the role of Cloud Computing in enhancing teaching and learning in the Saudi Arabian universities based on the principle of previous experiences?

- What is the role of Cloud Computing in enhancing teaching and learning in the Saudi Arabian universities based on the principle of the activity of the learner?

- What is the role of Cloud Computing in enhancing teaching and learning in the Saudi Arabian universities based on the principle of the development of mental skills?

\section{$3 \quad$ Aim of the Study}

In general, this research aims to identify the role of Cloud Computing for enhanced teaching and learning in the Saudi Arabian universities in accordance with the principles of the Social Constructivism Theory, from the point of view of the specialists. The objectives of the study are:

- To identify the role of Cloud Computing for enhanced teaching and learning in the Saudi Arabian universities based on the principle of social interaction from specialists' point of view.

- To identify the role of Cloud Computing for enhanced teaching and learning in the Saudi Arabian universities based on the principle of previous experiences from specialists' point of view.

- To identify the role of Cloud Computing for enhanced teaching and learning in the Saudi Arabian universities based on the principle of activity of the learners from the specialists' point of view.

- To identify the role of Cloud Computing for enhanced teaching and learning in the Saudi Arabian universities based on the principle of development of mental skills from the specialists' point of view.

\section{The Importance of the Study}

There is no dearth of studies on the use of Cloud Computing in higher education, and so are many studies on Social Constructivism Theory too but this study is characterized by a link between Cloud Computing and Social Constructivism Theory, which remains one of the most important educational theories today. 
This study not only investigates the role of Cloud Computing in teaching and learning in general, and in the Social Constructivism paradigm, which has been overlooked by the previous studies, especially in the context of Saudi Arabian universities.

Further, the results of this study will contribute to the development of e-learning which will help those leading the Deanships of e-learning and distance learning to develop e-learning at their universities by using Cloud Computing in the Social Constructivism paradigm.

Moreover, this study also helps to clarify the relationship between Cloud Computing and the Social Constructivism Theory.

In addition, the importance of this study lies in exploring the use of technology, including Cloud Computing and its services to support learning apart from the important role of teaching and learning based on the educational theories, including Social Constructivism Theory, which provides us with an opportunity to benefit from the technologies, in order to support and promote teaching and learning on sound educational principles and foundations.

\section{$5 \quad$ Research Methodology}

\subsection{Research approach}

This study was conducted across all Saudi Arabian government universities in the Kingdom of Saudi Arabia, consisting of 29 universities, with a quantitative approach based on a questionnaire being used to conduct the study.

\subsection{The population of the study}

The study's population consisted of the Deans and Vice Deans of e-learning Deanships in all Saudi Arabian government universities, whose total population was 98, represented by both male and female Deans and Vice Deans, in the academic year 2016/2017. The population consisted of the specialists in this area, and at the same time those who were responsible for the integration of technology in their respective universities in order to support and promote learning.

\subsection{Study sample}

The study sample included the entire study population, except those who did not complete the Questionnaire, with a total sample size of 84 male and female Deans and Vice deans of e-learning Deanships as a purposive sample, that represented 85.7 per cent of the total study community.

\subsection{The study tool}

The questionnaire was the study tool. 


\subsection{Building the tool of the study}

After reviewing the theoretical literature and the previous studies pertaining to the subject of this study, the researcher built the tool by starting with the preliminary questions about the initial data, including participants' name, university name, and specialization, which were all optional.

The four main sections related to the role of Cloud Computing in order to enhance teaching and learning in the Saudi Arabian universities, based on the principle of Social Constructivism Theory where the first section specific to the principle of social interaction, which included 11 questions. The second section was about the principle of previous experiences which contained five questions. The third section was related to the principle of the activity of the learner, which included 12 questions. Finally, the last section was about the principle of the development of the mental skills, which contained 7 questions.

It is worth mentioning that the Questionnaire was converted into an electronic Questionnaire, which facilitated the process of sending the study sample through e-mail and other electronic means of communication, in order to assist the study sample to complete and to return the Questionnaire quickly and easily.

Validity of the Tool: The veracity of the tool was ascertained by subjecting it to rigorous scrutiny for revalidation. It was presented to a group of experts, and based on the feedback, suitable modifications were made to make it foolproof.

Reliability of the Tool: The Alpha Cronbach coefficient was calculated to confirm the reliability of the tool, and as shown in Table 1 the tool of the study has a high degree of reliability.

Table 1. Cronbach's Alpha for All the Tool Sections

\begin{tabular}{|l|c|c|}
\hline \multicolumn{1}{|c|}{ Section } & No. of Items & Cronbach's Alpha \\
\hline Social interaction & 11 & 0.902 \\
\hline Previous Experience & 5 & 0.864 \\
\hline Activity of the Learner & 12 & 0.908 \\
\hline Development of Mental Skills & 7 & 0.883 \\
\hline & 35 & 0.959 \\
\hline
\end{tabular}

\subsection{Data analysis}

The data were analyzed by using the SPSS program, and used the following statistical methods of data analysis:

- Percentages, to describe the characteristics of the study sample.

- Cronbach's Alpha-Correlation, to determine the reliability of the study tool.

- Arithmetic Mean and Standard deviation to order the responses of the study sample.

When analyzed, the responses of the study sample were considered so that if the mean value was: 
- From (1) to (1.80), the degree of agreement from the point of view of the sample is very little.

- From (1.81) to (2.60), the degree of agreement from the point of view of the sample is little.

- From (2.61) to (3.40), the degree of agreement from the point of view of the sample is medium.

- From (3.41) to (4.20), the degree of agreement from the point of view of the sample is large.

- From (4.21) to (5), the degree of agreement from the point of view of the sample is very large.

This applies to the tool sections which apply to the questions on the Questionnaire, as in the previous division.

\section{The Results of the Study}

\subsection{Discussion}

To answer the study Questions, the researcher calculated the Means and Standard deviations for the sample responses about the role of Cloud Computing in enhancing teaching and learning in accordance with the four principles of social constructivism theory. Statements in Table 2, 3, 4 and 5 shows that ranked descending by mean according to the relative importance of each statement from the sample's self-reported perspectives, shown as the ratio of the per cent to total number of the sample.

The Role of Cloud Computing in Enhancing Teaching and Learning in Saudi Arabian Universities in the context of the Principle of Social Interaction

Table 2. Sample self-reported about the Role of Cloud Computing in Enhancing Teaching and Learning in the Saudi Arabian Universities based on the Principle of Social Interaction

\begin{tabular}{|c|c|c|c|c|c|c|c|}
\hline Statement & $\begin{array}{l}\text { Entirely } \\
\text { Disagree }\end{array}$ & Disagree & Neither & Agree & $\begin{array}{c}\text { Entirely } \\
\text { Agree }\end{array}$ & Mean & $\begin{array}{l}\text { Standard } \\
\text { Deviation }\end{array}$ \\
\hline \multirow{2}{*}{$\begin{array}{l}\text { Offers the opportunity to publish } \\
\text { teachers' audio and video lessons } \\
\text { on students' digital devices }\end{array}$} & 0 & 0 & 10 & 34 & 40 & \multirow{2}{*}{4.36} & \multirow{2}{*}{0.69} \\
\hline & $0.00 \%$ & $0.00 \%$ & $11.90 \%$ & $40.50 \%$ & $47.60 \%$ & & \\
\hline \multirow{2}{*}{$\begin{array}{l}\text { Contribute to the sharing of } \\
\text { knowledge }\end{array}$} & 0 & 0 & 7 & 44 & 33 & \multirow{2}{*}{4.31} & \multirow{2}{*}{0.62} \\
\hline & $0.00 \%$ & $0.00 \%$ & $8.30 \%$ & $52.40 \%$ & $39.30 \%$ & & \\
\hline \multirow{2}{*}{$\begin{array}{l}\text { Allows learners to interact with the } \\
\text { course instructor }\end{array}$} & 0 & 0 & 7 & 50 & 27 & \multirow{2}{*}{4.24} & \multirow{2}{*}{0.59} \\
\hline & $0.00 \%$ & $0.00 \%$ & $8.30 \%$ & $59.50 \%$ & $32.10 \%$ & & \\
\hline \multirow{2}{*}{$\begin{array}{l}\text { Contribute to transformation of } \\
\text { teaching device from sources of } \\
\text { communication and transfer of } \\
\text { information to sources of teaching } \\
\text { and learning interaction }\end{array}$} & 0 & 0 & 8 & 50 & 26 & \multirow[b]{2}{*}{4.21} & \multirow[b]{2}{*}{0.6} \\
\hline & $0.00 \%$ & $0.00 \%$ & $9.50 \%$ & $59.50 \%$ & $31.00 \%$ & & \\
\hline \multirow{2}{*}{$\begin{array}{l}\text { Allows learners to interact with } \\
\text { each other }\end{array}$} & 0 & 0 & 7 & 53 & 24 & \multirow{2}{*}{4.2} & \multirow{2}{*}{0.58} \\
\hline & $0.00 \%$ & $0.00 \%$ & $8.30 \%$ & $63.10 \%$ & $28.60 \%$ & & \\
\hline
\end{tabular}




\begin{tabular}{|c|c|c|c|c|c|c|c|}
\hline \multirow{2}{*}{$\begin{array}{l}\text { Gives students opportunity to know } \\
\text { about the results of their response } \\
\text { in any teaching and learning } \\
\text { process }\end{array}$} & 0 & 1 & 9 & 46 & 28 & \multirow[b]{2}{*}{4.2} & \multirow[b]{2}{*}{0.67} \\
\hline & $0.00 \%$ & $1.20 \%$ & $10.70 \%$ & $54.80 \%$ & $33.30 \%$ & & \\
\hline \multirow{2}{*}{$\begin{array}{l}\text { Encourage cooperative teaching } \\
\text { and learning in an interactive way }\end{array}$} & 0 & 2 & 12 & 40 & 30 & \multirow{2}{*}{4.17} & \multirow{2}{*}{0.76} \\
\hline & $0.00 \%$ & $2.40 \%$ & $14.30 \%$ & $47.60 \%$ & $35.70 \%$ & & \\
\hline \multirow{2}{*}{ Allows you to interact with content } & 0 & 0 & 10 & 51 & 23 & \multirow{2}{*}{4.15} & \multirow{2}{*}{0.61} \\
\hline & $0.00 \%$ & $0.00 \%$ & $11.90 \%$ & $60.70 \%$ & $27.40 \%$ & & \\
\hline \multirow{2}{*}{$\begin{array}{l}\text { Helps to provide feedback in a } \\
\text { timely manner }\end{array}$} & 0 & 0 & 14 & 47 & 23 & \multirow{2}{*}{4.11} & \multirow{2}{*}{0.66} \\
\hline & $0.00 \%$ & $0.00 \%$ & $16.70 \%$ & $56.00 \%$ & $27.40 \%$ & & \\
\hline \multirow{2}{*}{$\begin{array}{l}\text { Contribute to providing content in a } \\
\text { variety of interactive formats }\end{array}$} & & 1 & 13 & 46 & 24 & \multirow{2}{*}{4.11} & \multirow{2}{*}{0.69} \\
\hline & $0.00 \%$ & $1.20 \%$ & $15.50 \%$ & $54.80 \%$ & $28.60 \%$ & & \\
\hline \multirow{3}{*}{$\begin{array}{l}\text { Helps to use teaching and learning } \\
\text { activities for real life tasks }\end{array}$} & 0 & 0 & 10 & 57 & 17 & \multirow{2}{*}{4.08} & \multirow{2}{*}{0.56} \\
\hline & $0.00 \%$ & $0.00 \%$ & $11.90 \%$ & $67.90 \%$ & $20.20 \%$ & & \\
\hline & & & & & & 4.19 & 0.46 \\
\hline
\end{tabular}

6.2 Self-Reported Sample on the Role of Cloud Computing in Enhancing Teaching and Learning in Saudi Arabian Universities based on the Principle of Social Interaction

Table 2 shows respondents' feedback on the role of Cloud Computing in promoting education based on the principle of social interaction. The results show that $88.1 \%$ of the study sample (mean=4.36 and $\mathrm{SD}=0.69$ ) endorse that Cloud Computing "offered the opportunity to publish teachers' audio and video lessons on students' digital devices."

$91.7 \%$ (mean $=4.3$ and $\mathrm{SD}=0.62$ ) agreed that Cloud Computing "contributed to the sharing of knowledge". The table also shows that $91.6 \%($ mean $=4.24)$ and $\mathrm{SD}=0.59)$ agree that Cloud Computing "allowed the learners to interact with the course instructors". It is worth mentioning that despite the agreement, $88.1 \%$ of the study sample agreed that Cloud Computing "helped to use teaching and learning activities for the real-life tasks". However, it is the lowest (mean=4.08 and $\mathrm{SD}=0.56$ ) compared to the other services and roles provided by Cloud Computing.

It is clear from the total mean of the role of Cloud Computing in enhancing teaching and learning in the Saudi Arabian universities, based on the principle of social interaction (4.19), is quite large, which is primarily owing to many advantages of Cloud Computing services that support focus of social theory on the importance of social interaction in knowledge building. Cloud Computing provides many advantages and services which support social interaction, file and image sharing, and helps learner activities and interaction with the teachers and other learners.

Cloud Computing provides students with the ability to share teaching and learning materials, references, research papers, and scientific articles, to name a few, through the files stored on storage services in Cloud Computing (Al-Samarraie \& Saeed, 2018). Further, Denton (2012) has reported on the positive aspects of Cloud Computing in education, such as trough tools like Google Docs and Microsoft Office Live, which can support teaching methods based on the constructive and collaborative teaching and learning using Social Constructivism Theory. Cloud Computing facilitates easy access 
to knowledge content and research, websites for collaboration and knowledge building, enabling seamless exchange of knowledge between the students, faculty members, and researchers (Huang, 2017).

6.3 The Role of Cloud Computing in Enhancing Teaching and Learning in the Saudi Arabian Universities based on the Principle of Previous Experience

Table 3. Self-reported Sample on the Role of Cloud Computing in Enhancing Teaching and Learning in the Saudi Arabian Universities based on the Principle of Previous Experience

\begin{tabular}{|c|c|c|c|c|c|c|c|}
\hline Statement & $\begin{array}{l}\text { Entirely } \\
\text { Disagree }\end{array}$ & Disagree & Neither & Agree & $\begin{array}{c}\text { Entirely } \\
\text { Agree }\end{array}$ & Mean & $\begin{array}{l}\text { Standard } \\
\text { Deviation }\end{array}$ \\
\hline \multirow{2}{*}{$\begin{array}{l}\text { Helps to integrate students' } \\
\text { experiences in acquiring knowledge }\end{array}$} & 0 & 0 & 16 & 51 & 17 & \multirow{2}{*}{4.01} & \multirow{2}{*}{0.63} \\
\hline & $0.00 \%$ & $0.00 \%$ & $19.00 \%$ & $60.70 \%$ & $20.20 \%$ & & \\
\hline \multirow{2}{*}{$\begin{array}{l}\text { Gives learners enough time to } \\
\text { meditate in new experiences }\end{array}$} & 0 & 2 & 17 & 46 & 19 & \multirow{2}{*}{3.98} & \multirow{2}{*}{0.73} \\
\hline & $0.00 \%$ & $2.40 \%$ & $20.20 \%$ & $54.80 \%$ & $22.60 \%$ & & \\
\hline \multirow{2}{*}{$\begin{array}{l}\text { Helps to build knowledge based on } \\
\text { previous knowledge and experience }\end{array}$} & 1 & 1 & 16 & 48 & 18 & \multirow{2}{*}{3.96} & \multirow{2}{*}{0.75} \\
\hline & $1.20 \%$ & $1.20 \%$ & $19.00 \%$ & $57.10 \%$ & $21.40 \%$ & & \\
\hline \multirow{2}{*}{$\begin{array}{l}\text { Contributes to linking previous } \\
\text { knowledge with subsequent } \\
\text { knowledge }\end{array}$} & 1 & 2 & 17 & 51 & 13 & \multirow[b]{2}{*}{3.87} & \multirow[b]{2}{*}{0.74} \\
\hline & $1.20 \%$ & $2.40 \%$ & $20.20 \%$ & $60.70 \%$ & $15.50 \%$ & & \\
\hline \multirow{3}{*}{$\begin{array}{l}\text { Helps to explore learners' previous } \\
\text { teaching and learning experiences }\end{array}$} & 0 & 4 & 27 & 38 & 15 & \multirow{2}{*}{3.76} & \multirow{2}{*}{0.8} \\
\hline & $0.00 \%$ & $4.80 \%$ & $32.10 \%$ & $45.20 \%$ & $17.90 \%$ & & \\
\hline & & & & & & 3.92 & 0.59 \\
\hline
\end{tabular}

6.4 Self-Reported Sample on the Role of Cloud Computing in Enhancing Teaching and Learning in the Saudi Arabian Universities based on the Principle of Previous Experience

Table (3) shows respondents' opinions on the role of Cloud Computing in enhancing teaching and learning in the Saudi Arabian universities based on the principle of previous experience. The table shows that $80.9 \%$ (mean $=4.01$ and $\mathrm{SD}=0.63$ ) of the study sample agreed that Cloud Computing "helped to integrate students' experiences in acquiring knowledge". This may be due to the nature of Cloud Computing services that gives the users opportunity to build new experiences through their previous experiences. The results also show that $77.4 \%$ (mean $=3.98$ and $\mathrm{SD}=0.73$ ) of the sample believed that Cloud Computing "gave the learners enough time to meditate in the new experiences", and that the learner used Cloud Computing based on his/her own speed and abilities.

In general, the total mean (3.92\%) shows larger role of Cloud Computing in enhancing teaching and learning in the Saudi Arabian universities in the light of previous experiences.

Furthermore, Denton (2012) reported on the advantages of the services of Cloud Computing in the education field, such as Google Docs and Microsoft Office Live, 
which have the potentiality to promote and support teaching methods based on the constructive and collaborative teaching and learning by using the Social Constructivism Theory.

\subsection{The Role of Cloud Computing in Enhancing teaching and Learning in the Saudi Arabian universities based on the Principle of Activity of a Learner}

Table 4. Sample Self-reported about the Role of Cloud Computing in Enhancing Teaching and Learning in the Saudi Arabian Universities based on the Principle of Activity of a Learner

\begin{tabular}{|c|c|c|c|c|c|c|c|}
\hline Statement & $\begin{array}{l}\text { Entirely } \\
\text { Disagree }\end{array}$ & Disagree & Neither & Agree & $\begin{array}{c}\text { Entirely } \\
\text { Agree }\end{array}$ & Mean & $\begin{array}{l}\text { Standard } \\
\text { Deviation }\end{array}$ \\
\hline \multirow{2}{*}{ Encourages self-learning } & 0 & 1 & 4 & 41 & 38 & \multirow{2}{*}{4.38} & \multirow{2}{*}{0.64} \\
\hline & $0.00 \%$ & $1.20 \%$ & $4.80 \%$ & $48.80 \%$ & $45.20 \%$ & & \\
\hline \multirow{2}{*}{$\begin{array}{l}\text { Helps the learner to have an active role } \\
\text { in the teaching and learning process }\end{array}$} & 0 & 0 & 6 & 47 & 31 & \multirow{2}{*}{4.3} & \multirow{2}{*}{0.6} \\
\hline & $0.00 \%$ & $0.00 \%$ & $7.10 \%$ & $56.00 \%$ & $36.90 \%$ & & \\
\hline \multirow{2}{*}{$\begin{array}{l}\text { Contributes to transforming the role of } \\
\text { academic staff from a microcontroller } \\
\text { in the teaching and learning process to a } \\
\text { facilitator of learning }\end{array}$} & 0 & 0 & 12 & 38 & 34 & \multirow[b]{2}{*}{4.26} & \multirow[b]{2}{*}{0.7} \\
\hline & $0.00 \%$ & $0.00 \%$ & $14.30 \%$ & $45.20 \%$ & $40.50 \%$ & & \\
\hline \multirow{2}{*}{$\begin{array}{l}\text { Helps to diversify teaching strategies } \\
\text { that focus on the learner }\end{array}$} & 0 & 0 & 9 & 46 & 29 & \multirow{2}{*}{4.24} & \multirow{2}{*}{0.63} \\
\hline & $0.00 \%$ & $0.00 \%$ & $10.70 \%$ & $54.80 \%$ & $34.50 \%$ & & \\
\hline \multirow{2}{*}{$\begin{array}{l}\text { Contributes to the promotion of } \\
\text { education that gives students freedom } \\
\text { of performance and achievement based } \\
\text { on their own speed and ability }\end{array}$} & 0 & 0 & 9 & 56 & 19 & \multirow[b]{2}{*}{4.12} & \multirow[b]{2}{*}{0.57} \\
\hline & $0.00 \%$ & $0.00 \%$ & $10.70 \%$ & $66.70 \%$ & $22.60 \%$ & & \\
\hline \multirow{2}{*}{$\begin{array}{l}\text { Helps learners to engage in a variety of } \\
\text { activities }\end{array}$} & 0 & 1 & 11 & 52 & 20 & \multirow{2}{*}{4.08} & \multirow{2}{*}{0.64} \\
\hline & $0.00 \%$ & $1.20 \%$ & $13.10 \%$ & $61.90 \%$ & $23.80 \%$ & & \\
\hline \multirow{2}{*}{$\begin{array}{l}\text { Contributes to the investment of the } \\
\text { greatest degree of abilities of learners }\end{array}$} & 0 & 2 & 12 & \begin{tabular}{|l|}
47 \\
\end{tabular} & 23 & \multirow{2}{*}{4.08} & \multirow{2}{*}{0.71} \\
\hline & $0.00 \%$ & $2.40 \%$ & $14.30 \%$ & $56.00 \%$ & $27.40 \%$ & & \\
\hline \multirow{2}{*}{ Encourages learners' motivation } & 0 & 2 & 11 & 50 & 21 & \multirow{2}{*}{4.07} & \multirow{2}{*}{0.69} \\
\hline & $0.00 \%$ & $2.40 \%$ & $13.10 \%$ & $59.50 \%$ & $25.00 \%$ & & \\
\hline \multirow{2}{*}{$\begin{array}{l}\text { Helps to focus the teaching and learning } \\
\text { environment around the student }\end{array}$} & 0 & 2 & 16 & \begin{tabular}{|l|}
44 \\
\end{tabular} & \begin{tabular}{|l|}
22 \\
\end{tabular} & \multirow{2}{*}{4.02} & \multirow{2}{*}{0.74} \\
\hline & $0.00 \%$ & $2.40 \%$ & $19.00 \%$ & $52.40 \%$ & $26.20 \%$ & & \\
\hline \multirow{2}{*}{$\begin{array}{l}\text { Provides an opportunity for learners to } \\
\text { assess their own learning }\end{array}$} & 0 & 1 & 16 & 50 & 17 & \multirow{2}{*}{3.99} & \multirow{2}{*}{0.67} \\
\hline & $0.00 \%$ & $1.20 \%$ & $19.00 \%$ & $59.50 \%$ & $20.20 \%$ & & \\
\hline \multirow{2}{*}{$\begin{array}{l}\text { Contributes to the diversification of } \\
\text { evaluation strategies to understand the } \\
\text { actual changes that occurred to the } \\
\text { student as a result of passing through } \\
\text { teaching and learning experiences }\end{array}$} & 0 & 2 & 15 & 52 & 15 & \multirow[b]{2}{*}{3.95} & \\
\hline & $0.00 \%$ & $2.40 \%$ & $17.90 \%$ & $61.90 \%$ & $17.90 \%$ & & 0.67 \\
\hline Contributes to the face of individual & 0 & 3 & 19 & \begin{tabular}{|l|}
46 \\
\end{tabular} & 16 & & \\
\hline & $0.00 \%$ & $3.60 \%$ & $22.60 \%$ & $54.80 \%$ & $19.00 \%$ & 3.8 & \\
\hline & & & & & & 4.12 & 0.47 \\
\hline
\end{tabular}


6.6 Self-reported Sample on the Role of Cloud Computing in Enhancing Teaching and Learning in the Saudi Arabian Universities based on the Principle of Activity of the Learners

Table (4) shows respondents' feedback on the role of Cloud Computing in enhancing teaching and learning in the Saudi Arabian universities in the context of the activity of the learners. The Table shows that $94 \%$ (mean $=4.38$ and $\mathrm{SD}=0.64$ ) of the study sample agreed that Cloud Computing "encouraged self-learning". The results show that $92.9 \%$ of the study sample (mean $=4.30$ and $\mathrm{SD}=0.60$ ) agree that Cloud Computing "helped the learner to have an active role in the teaching and learning process". The results also show that $85.7 \%$ (mean=4.26 and $\mathrm{SD}=0.70$ ) of the sample believe that Cloud Computing "contributes to transforming the role of academic staff from a microcontroller in the teaching and learning process to a facilitator of learning".

In general, it is clear from the total mean (4.12) that the role of Cloud Computing in enhancing teaching and learning in Saudi Arabia in the context of the activity of the learner is significant.

It may be due to the foundations of most Cloud Computing services, where the focus is on the users playing a significant role in content management and self-reliance in acquiring knowledge, and the effectiveness of the learner which is consistent with the third principle of the Social Constructivism Theory, where focus was on the activity of the learner in the teaching and learning process.

Cloud Computing has many new ways of thinking about various areas such as teaching and learning design, teaching and learning experiences, interaction and adapting Cloud environments to user needs, and opening up the potentialities to deliver a common experience which will stimulate new types of requirements, needs, and user activities (Sun \& Shu, 2016).

6.7 The Role of Cloud Computing in Enhancing Teaching and Learning in the Saudi Arabian Universities Based on the Principle of Development of Mental Skills

Table 5. Sample Self-reported about the Role of Cloud Computing in Enhancing Teaching and Learning in the Saudi Arabian Universities based on the Principle of Development of Mental Skills

\begin{tabular}{|c|c|c|c|c|c|c|c|}
\hline Statement & $\begin{array}{l}\text { Entirely } \\
\text { Disagree }\end{array}$ & Disagree & Neither & Agree & $\begin{array}{c}\text { Entirely } \\
\text { Agree }\end{array}$ & Mean & $\begin{array}{l}\text { Standard } \\
\text { Deviation }\end{array}$ \\
\hline \multirow{2}{*}{$\begin{array}{l}\text { Contributes to } \\
\text { diversity of access to } \\
\text { information }\end{array}$} & 0 & 1 & 6 & 48 & 29 & \multirow{2}{*}{4.25} & \multirow{2}{*}{0.64} \\
\hline & $0.00 \%$ & $1.20 \%$ & $7.10 \%$ & $57.10 \%$ & $34.50 \%$ & & \\
\hline \multirow{3}{*}{$\begin{array}{l}\text { Encourages focus on } \\
\text { skills development } \\
\text { more than } \\
\text { information transfer }\end{array}$} & 0 & 2 & 12 & 41 & 29 & \multirow[b]{2}{*}{4.15} & \multirow[b]{2}{*}{0.75} \\
\hline & $0.00 \%$ & $2.40 \%$ & $14.30 \%$ & $48.80 \%$ & $34.50 \%$ & & \\
\hline & 0 & 1 & 10 & 48 & 25 & 4.15 & 0.67 \\
\hline
\end{tabular}




\begin{tabular}{|c|c|c|c|c|c|c|c|}
\hline $\begin{array}{l}\text { Encourages the } \\
\text { proposal of diverse } \\
\text { ideas }\end{array}$ & $0.00 \%$ & $1.20 \%$ & $11.90 \%$ & $57.10 \%$ & $29.80 \%$ & & \\
\hline \multirow[b]{2}{*}{$\begin{array}{l}\text { Contributing to the } \\
\text { transfer of university } \\
\text { teaching from } \\
\text { teaching facts to } \\
\text { teaching and learning } \\
\text { concepts and } \\
\text { investing in solving } \\
\text { problems }\end{array}$} & 1 & 1 & 10 & 47 & 25 & & \\
\hline & $1.20 \%$ & $1.20 \%$ & $11.90 \%$ & $56.00 \%$ & $29.80 \%$ & 4.12 & 0.75 \\
\hline \multirow{2}{*}{$\begin{array}{l}\text { Helps to target higher } \\
\text { thinking levels }\end{array}$} & 0 & 2 & 16 & 43 & 23 & \multirow{2}{*}{4.04} & \multirow{2}{*}{0.75} \\
\hline & $0.00 \%$ & $2.40 \%$ & $19.00 \%$ & $51.20 \%$ & $27.40 \%$ & & \\
\hline \multirow{2}{*}{$\begin{array}{l}\text { Helps to develop } \\
\text { creative thinking }\end{array}$} & 1 & 2 & 15 & 43 & 23 & \multirow{2}{*}{4.01} & \multirow{2}{*}{0.81} \\
\hline & $1.20 \%$ & $2.40 \%$ & $17.90 \%$ & $51.20 \%$ & $27.40 \%$ & & \\
\hline \multirow{3}{*}{$\begin{array}{l}\text { Helps to express } \\
\text { ideas }\end{array}$} & 1 & 5 & 9 & 47 & 22 & \multirow{2}{*}{4} & \multirow{2}{*}{0.85} \\
\hline & $1.20 \%$ & $6.00 \%$ & $10.70 \%$ & $56.00 \%$ & $26.20 \%$ & & \\
\hline & & & & & & 4.10 & 0.57 \\
\hline
\end{tabular}

6.8 Self-Reported Sample on the Role of Cloud Computing in Enhancing Teaching and Learning in the Saudi Arabian Universities Based on the Principle of Development of Mental Skills

Table 5 shows respondents' views on the role of Cloud Computing in enhancing teaching and learning in the Saudi Arabian universities based on the principle of the development of mental skills. The results show that $91.6 \%$ of the study sample (mean $=4.25$ and $\mathrm{SD}=0.64$ ) agreed that Cloud Computing "contributed to the diversity of access to information". The results also show that $83.3 \%$ (mean $=4.15$ and $\mathrm{SD}=0.75$ ) of the sample believed that Cloud Computing "encouraged focus on skills development more than information transfer". Also, more than three-quarters of the sample $78.6 \%$ (mean=4.04 and $\mathrm{SD}=0.75$ ) agreed that Cloud Computing "helped to target higher thinking levels".

In general, the total mean (4.10) shows a larger role of Cloud Computing in enhancing teaching and learning in the Saudi Arabian universities based on the principle of the development of mental skills.

The study by Hussona (2016) conducted at Al-Aqsa University which confirmed the effectiveness of Cloud Computing in teaching and learning and training, and for developing skills in the use of Cloud Computing. 


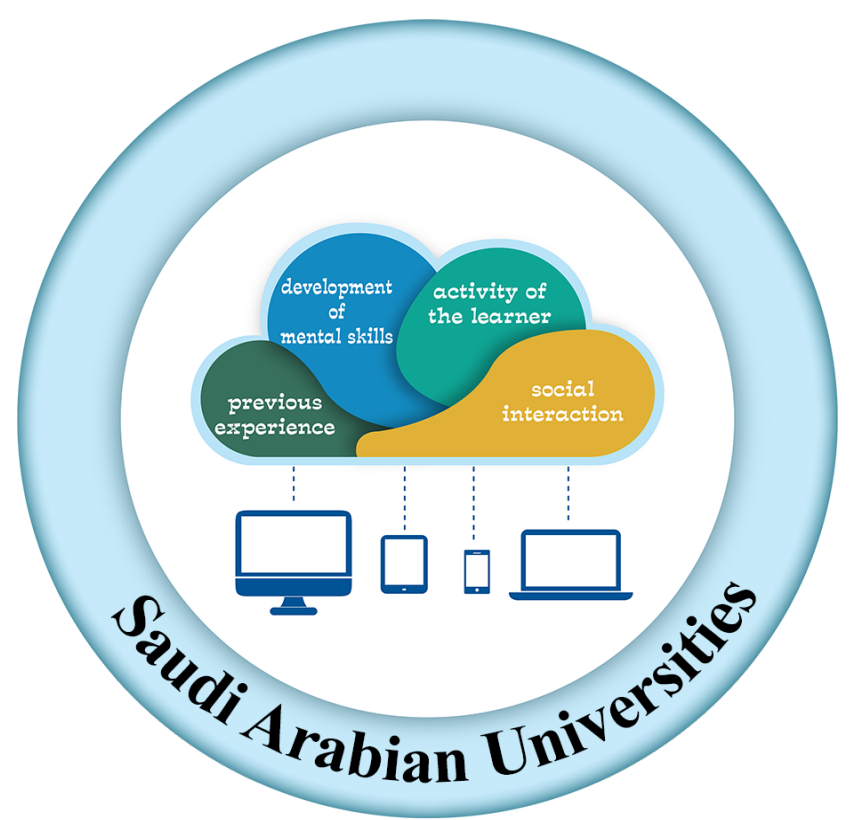

Fig. 1. The Role of Cloud Computing in Enhancing Teaching and Learning at the Saudi Arabian Universities in Accordance with the Social Constructivism Theory

\section{Recommendations}

This researcher has following recommendations for the future research initiatives on Cloud Computing to enhance teaching and learning in the universities in accordance with the Social Constructivism Theory. They will have ample scope to present a unified research outcome through the following:

- Adoption of Cloud Computing in teaching and learning and teaching environments in the universities.

- Spreading the culture to use Cloud Computing in teaching and learning among the universities' faculty members.

- Intensive training sessions for the faculty members to develop their skills in the use of Cloud Computing in education effectively.

- Encouragement of students to use Cloud Computing in the teaching and learning environments.

\section{Conclusion}

This research concludes with the findings and a blueprint for the further research. It is clear that there is a very critical role for Cloud Computing in enhancing teaching and learning in the Saudi Arabian universities on the lines s of the four principles of Social 
Constructivism Theory (a: Social Interaction; b: Previous Experiences; c: Activity of the Learner and the d: the Development of Mental Skills), from the point of view of the specialists who are responsible for the integration of technology in order to support the teaching and learning initiatives in the universities.

\section{References}

[1] Alfifi, F., (2015). Factors Influencing the Adoption of Cloud Computing by CIOs and Decision Makers in Higher Education Institutions, Doctoral Dissertation, Robert Morris University.

[2] Alghamdi, S., \& Beloff, N., (2014). Towards a comprehensive model for e-Government adoption and utilization analysis: The case of Saudi Arabia. In Computer Science and Information Systems (FedCSIS), 2014 Federated Conference on FedCSIS). IEEE, 12171225. https://doi.org/10.15439/2014f146

[3] Al-Samarraie, H., \& Saeed, N. (2018). A systematic review of cloud computing tools for collaborative learning: Opportunities and challenges to the blended-learning environment. Computers \& Education, 124, 77-91. $\underline{\text { https://doi.org/10.10 }}$ 16/j.compedu.2018.05.016

[4] Alt, D., (2014). The construction and validation of a new scale for measuring features of constructivist learning environments in higher education, in Frontline Learning Research, (2)3, $1-27$.

[5] Arpaci, I., (2017). Antecedents and consequences of Cloud Computing adoption in education to achieve knowledge management. Computers in Human Behavior. https://doi.org/10.1016/j.chb.2017.01.024

[6] Bhatiasevi, V., \& Naglis, M., (2016). Investigating the structural relationship for the determinants of Cloud Computing adoption in education. Education and Information Technologies, 21(5), 1197-1223. https://doi.org/10.1007/s10639-015-9376-6

[7] Buckner, E., (2017). The worldwide growth of private higher education: Cross-national patterns of higher education institution foundings by sector. Sociology of Education, 90(5), 296-314. https://doi.org/10.1177/0038040717739613

[8] Business Monitor International (2015): Saudi Arabia Information Technology Report - Q2 2015. www.bmiresearch.com.

[9] Changchit, Chuleeporn (2014). Students' perceptions of Cloud Computing, Issues in Information Systems, 15(1), 312-322.

[10] Cisco, (2016). Cisco Global Cloud Index: Forecast and Methodology, 2014-2019 White Paper.

[11] Dahlberg, T., Kivijärvi, H., \& Saarinen, T., (2017). Longitudinal study on the expectations of Cloud Computing benefits and an integrative multilevel model for understanding Cloud Computing performance. In Proceedings of the 50th Hawaii International Conference on System Sciences. https://doi.org/10.24251/hicss.2017.514

[12] Denton, D.W., (2012). Enhancing instruction through constructivism, cooperative learning, and cloud computing. TechTrends, 56(4), 34-41. https://doi.org/10.1007/s11528-012-05851

[13] Freiberg, H.J., \& Driscoll, A., (2000). Universal Teaching Strategies, Allyn \& Bacon.

[14] Hussona, E.O., (2016). Impact of Cloud Computing-based e-Training (CCBT) on developing skills and usage acceptance thereof among education faculty students of Al-Aqsa 
University, Palestinian Journal of Open \& Distance Education, 5(10), 165-20. https://doi.org/10.12816/0027535

[15] Huang, L., \& Liu, C., (2013). Construction of collaborative learning environment supported by Cloud Computing, Proceedings of the $2^{\text {nd }}$ International Conference on Computer Science and Electronics Engineering (ICCSEE 2013), Paris: Atlantis Press, 1322 - 1325. https://doi.org/10.2991/iccsee.2013.331

[16] Huang, Y.M., (2017). Exploring the intention to use Cloud services in collaboration contexts among Taiwan's private vocational students, Information Development, 33(1), 2942. https://doi.org/10.1177/0266666916635223

[17] Ismail, Z.M., (2016). The impact of different management style sessions in Cloud Computing for the development of participatory learning skills I have the satisfaction of education and educational technology students towards it, Arabic Studies in Education and Psychology, 72, 255-302. https://doi.org/10.12816/0036691

[18] Jalgaonkar, M., \& Kanojia, A., (2013). Adoption of Cloud Computing in distance learning, International Journal of Advanced Trends in Computer Science and Engineering, (2)1, 17 20.

[19] Li, T. (2018). Construction and Implementation of Network Teaching Platform for Design Art Education Based on Cloud Technology. Kuram ve Uygulamada Egitim Bilimleri, 18(5), $1738-1746$.

[20] Li, X., (2016). Design and application of multimedia teaching video system for dance major based on Cloud Computing technology, International Journal of Emerging Technologies in Learning, 11(5). https://doi.org/10.3991/ijet.v11i05.5689

[21] McDougall, J. (2015) The quest for authenticity: A study of an online discussion forum and the needs of adult learners', in Australian Journal of Adult Learning, 55(1), 94-113.

[22] Mell, P., \& Grance, T., (2011). The NIST Definition of Cloud Computing. Recommendations of the National Institute of Standards and Technology, NIST Special Publication, 800- 145. https://doi.org/10.6028/nist.sp.800-145

[23] Mitakos, T., Almaliotis, I., Diakakis, I., \& Demerouti, A., (2014). An insight on e-Learning and Cloud Computing systems, Informatica Economica, 18(4), 14. https://doi.org/10.12 $\underline{948 / \text { issn14531305/18.4.2014.02 }}$

[24] Murah, M.Z., (2012). Teaching and learning Cloud Computing, Procedia-Social and Behavioral Sciences, 59, 157-163. https://doi.org/10.1016/j.sbspro.2012.09.260

[25] Naidu, V. R., Bhat, A. Z., \& Singh, B. (2019). Cloud Concept for Implementing Multimedia Based Learning in Higher Education. In Smart Technologies and Innovation for a Sustainable Future (pp. 81-84). Springer, Cham. https://doi.org/10.1007/978-3-030-01659$\underline{3 \_11}$

[26] Powell, Katherine C., \& Cody J. Kalina (2009). Cognitive and social constructivism: developing tools for an effective classroom. Education, 130(2). 241+. Academic One File.

[27] Sabi, H.M., Uzoka, F.M.E., Langmia, K., \& Njeh, F.N., (2016). Conceptualizing a model for the adoption of Cloud Computing in education, International Journal of Information Management, 36(2), 183-191. https://doi.org/10.1016/j.ijinfomgt.2015.11.010

[28] Sun, Z., \& Shu, Y., (2016). Analysis of blended learning scheme based on Cloud Computing assisted instructions, International Journal of Emerging Technologies in Learning, 11(3). https://doi.org/10.3991/ijet.v11i03.5535

[29] Tashkandi, A.N., \& Al-Jabri, I.M., (2015). Cloud Computing adoption by higher education institutions in Saudi Arabia: An exploratory study, Cluster Computing, 18(4), 1527-1537. https://doi.org/10.1007/s10586-015-0490-4

[30] Vance, T.C., Merati, N., Yang, C., \& Yuan, M., (Eds.) (2016). Cloud Computing in Ocean and Atmospheric Sciences. Elsevier. 
[31] Vygotsky, L.S., (1978). Mind in Society: The Development of Higher Mental Process, Cambridge: Harvard University Press.

[32] Wray, D., \& Lewis, M., (1997). Extending literacy: Children Reading and Writing Nonfiction, Psychology Press.

[33] Zafar, F., Khan, A., Malik, S.U.R., Ahmed, M., Anjum, A., Khan, M.I. \& Jamil, F., (2017). A survey of Cloud Computing data integrity schemes: Design challenges, taxonomy and future trends. Computers \& Security, 65, 29-49. https://doi.org/10.1016/j.cose.2016.10.006

\section{Public Interest Statement}

Cloud Computing has become a reality today as far as its uses in the multiple forms are concerned. Universities and other institutions of higher learning can't ignore the role of Cloud Computing in the current scenario even as Information Technology has a greater say in each and every sector. This research had been conducted in the context of the Saudi Arabian government universities to assess the role of Cloud Computing in enhancing teaching and learning experience in the concerned universities.

One new dimension being incorporated, was the role of Cloud Computing in accordance with the context of the Social Constructivist paradigm as seen through a specialist educationalist point of view. This research thus brought to fore the relationship between Cloud Computing and Social Constructivism Theory in the context of the educational system in Saudi Arabia. It will greatly help all the stakeholders in understanding this perspective.

\section{Author}

Dr. Farhan Yetaim Alenezi is currently Vice Dean at the Deanship of E-Learning \& Distance Learning at Northern Border University (NBU), Arar, Kingdom of Saudi Arabia. The Lancaster University in the United Kingdom awarded him $\mathrm{PhD}$ in Educational Technology in 2014. Prior to that, he did his Master of Arts in Educational Technology from King Saud University, Saudi Arabia. He is member of several committees including Scientific Committee \& Committee for Admission \& Registration at NBU in the capacity of Vice Dean. He is also the Chairman of the Committee of Education Faculty Website at NBU.

As subject expert, he has participated in several national and international Conferences in Educational Technology. He has attended conferences in the USA and the UK on the themes of training courses in e-learning to self-development et al. He has published research papers in several reputed journals.

Article submitted 2018-09-18. Resubmitted 2018-11-17. Final acceptance 2018-11-18. Final version published as submitted by the authors. 